\title{
The Correlation between the Blood Sugar and Allergy of the Trauma Patient
}

\author{
Jeong Soo Lee ${ }^{1,2}$, Sung Hee Hyun ${ }^{1,2}$, Ji-Sook Lee ${ }^{3}$, and In Sik Kim ${ }^{1,2}$ \\ ${ }^{1}$ Department of Biomedical Laboratory Science, School of Medicine, Eulji University, Daejeon 301-746, Korea \\ ${ }^{2}$ Department of Senior Healthcare, BK21 plus program, Graduated School, Eulji University, Daejeon 301-746, Korea \\ ${ }^{3}$ Department of Clinical Laboratory Science, Wonkwang Health Science University, Iksan 570-750, Korea
}

\begin{abstract}
Research on the correlation between blood glucose and allergy of the trauma patient, and the changes of blood glucose after the injection of antibiotic Cephalosporins have been made in this study. In this research, we have investigated whether there is any correlation between allergies and blood glucose, and the changes of blood glucose after the injection of Cephalosporins. In case of the patients who have allergies, there has been a close correlationship between allergies and blood glucose by increasing the risk of developing sugar diabetes significantly to 3.273. And it showed that there is a correlation between Cephalosporins and glucose by the figure of Cephalosporins, before and one week after the operation, to become $r=1 * * . *$, bilateral significance probability ( $p$ $<0.007)$. There has been significant changes in blood glucose $(p<0.010)$, bun $(p<0.025)$, Albumin $(p<0.000)$, AST $(p<0.001)$, total bilirubin $(p<0.001)$ after the operation. It considered to be important indicator. preventing complications and allergies caused by diabetic history and also correlated $(p<0.027)$ because there is allergy and the patient's.
\end{abstract}

Keywords: Trauma patients, Allergy, Blood sugar, Cephalosporins

This is an Open Access article distributed under the terms of the Creative Commons Attribution Non-Commercial License (http://creativecommons.org/licenses/by-nc/3.0) which permits unrestricted non-commercial use, distribution, and reproduction in any medium, provided the original work is properly cited.

Copyright ( 2014 The Korean Society for Clinical Laboratory Science. All rights reserved.
Corresponding author: In Sik Kim

Department of Biomedical Laboratory Science, School of Medicine, Eulji University, Daejeon 301-746, Korea

Tel: 82-42-259-1753

E-mail: orientree@eulji.ac.kr

Received: February 25, 2014

Revised: March 17, 2014

Accepted: March 20, 2014

\section{서 론}

알레르기는 알레르겐에 노출되었을 때 $\mathrm{IgE}$ 의 과도한 분비로 인 하여 발생한다(Toyota 등, 2013). 알레르기 질환의 원인은 꽃가루, 오존 및 곰팡이의 공중 알레르기 항원의 농도에 의해 태풍 및 호우 가 천식 알레르기 질환을 증가 시킨다(Park 등, 2013). 천식의 만성 기침은 몸의 쇠약 증상을 나타내는 요인이며(Cornere 등, 2013), 기름 유출에 노출된 어린이는 천식 발병률이 높다(Simms 등, 2013). 천식에서 $\mathrm{T}$ 세포의 중심 역할을 지원하는 증거는 있지만, 다 른 천식 표현형에 질병을 움직여 알레르기 유발 $\mathrm{T}$ 세포 사이토킨의 역할은 불분명한 것으로 되어 있다(Pouliot 등, 1992). 알레르기 항 원에 대한 말초 혈액 단핵세포의 사이토킨 반응은 질병 상태, 아토 피 상태 또는 천식 기관지염의 종류 사이의 구별에 도움이 되지 않 는다(Holgate, 2013). 자연적인 규제 T (Treg) 세포는 알레르기성 천식 환자에서 염증 반응의 조절에 관여하며(Kinoshita 등, 2013), 비만 세포는 천식 알레르기와 타고난 면역 반응에 관여한다(DE
Boer 등, 2013). 어린이 천식 환자의 BMI와 산화질소(Fractional Exhaled Nitric Oxide)가 상관관계가 있음이 보고 되었다 (Erkoçoglu 등, 2013) 사람 라이노 바이러스는 천식 악화의 가장 흔한 원인이며(Becker 등, 2013), 천식과 기도 상피 세포의 가장 흔 한 급성 원인이다(Parsons 등, 2013). 만성 폐쇄성 폐 질환 및 천식 이 있는 사람과 중복 증후군을 가진 사람들은 사망률이 높다 (Pleasants 등, 2013). Neuropilin 1 (NP1)은 semaphorin 3A (SEMA 3A)와 천식의 병인에 관여 중요한 매개체 중 하나이다 (Shim 등, 2013). 아나필락시스의 가장 일반적인 원인은 땅콩과 견 과류, 약물, 음식, 곤충 독이며, 사망을 일으키는 아나필락시스 쇼 크는 식물 섭취 후 한 시간 안에 일어난다. 효과적인 치료는 아드레 날린 주사 처방이다(Laemmle 등, 2013). 약물 과민 증후군은 발 열, 피부 발진 및 내부 장기 침범이 특징이며(Bamanikar 등, 2013), 4 antituberculosis 약물로 아이소니아지드, 에탐부톨, 리팜피신, 그리고 흉막 결핵의 치료에 쓰이는 morphazinamide, 항생제 세프 트라이악손 등이(Ozkaya 등. 2013), 드물게 생명을 위협한다 
(Arulraj 등, 2013). 치과에서 혈관 수축제로 널리 사용하는 에피네 프린의 과민반응이 심혈관 합병증과 관련이 있을 때는 환자에게 치 명적일 수 있다(Jang 등, 2013). 에토포사이드는 일반적으로, 종양 의 다양한 치료에 사용되는 과민 에토포사이드에 대한 반응이 드물 게 보고되고, 저혈압, 고혈압, 홍조, 발한, 가슴 통증, 호흡 곤란, 기 관지 경련 및 의식을 잃을 수 있다(Lazovic 등, 2013).

대부분 당뇨병은 광범위하게 1형과 2형 두 가지 병인으로 분류 된다. 1 형 당뇨병 환자는 췌장 세포의 자기 면역성 파괴로 인하여 인슐린분비의 절대적 결핍에 의하며, 전형적으로 급작스럽게 발병 하고, 평생 인슐린 투여를 하여야 한다. 우리나라의 경우 1 형 당뇨 병 환자의 빈도는 전체 당뇨병 환자의 $5 \sim 10 \%$ 정도를 차지한다. 전 형적인 2형 당뇨병 환자는 40 대 이후에 발병하고 비만한 경우가 많 으며, 전체 당뇨병 환자의 90 95\%를 차지한다. 당뇨병은 대부분 국가에서 조기 이환과 사망의 주요 원인이 되고 있으며, 이는 주로 심혈관계 질환의 위험이 증가함으로 인한 것이다. 심혈관계 질환은 당뇨병 환자의 50 80\%를 차지한다. 당뇨병의 $90 \%$ 를 차지하는 2 형 당뇨병은 전 세계적으로 빠르게 증가하고 있으며, 2000년에서 2025년 사이에 유병률이 거의 두 배 가까이 증가하여 2025년까지 전 세계적으로 3 억 명 이상이 될 것으로 예측되고 있다. 그리고 당 뇨병을 않고 있는 동안 미세 혈관 합병증인 신경병증, 신장병 증의 발생률과 유병률이 증가한다(박, 2011). 당뇨성 콩팥 증은 1형 당 뇨에서 20 40\%, 2형에서는 10 20\%가 발생한다. 또한, 뇌중풍, 협심증, 심근경색 같은 혈관 합병증으로 당뇨병 환자의 60 70\% 가 사망을 하며, 미세 알부민뇨를 가진 당뇨병 환자는 심혈관 질환 사망률이 높다(Waanders 등, 2013).

고혈당 응급 입원 환자는 다른 환자에 비해 상당히 사망률이 높 다. 당뇨병의 조절이 양호할수록 인지기능, 일상생활 능력이 양호 하다. 병이 있는 기간이 길수록 일상생활 능력이 떨어지고 우울증 정도가 심해지며, 당뇨병 조절이 양호할수록 인지 기능, 일상생활 능력이 양호하다(정. 2011). 당뇨병 환자는 일반인보다 스트레스 정도가 심하고, 스트레스가 심할수록 혈당 조절이 잘 안 되며, 우울 증의 위험도가 올라간다(박, 2011). Cephalosporin은 1954년 의 사인 Brotzu에 의해 분리된 cephalosporium acremonium이 생 산하는 항생물질로서 그람 양성균과 그람 음성균의 발육을 저해하 며, 독성이 매우 약하다. 페니실린 분해효소에 의해 분해되지 않으 므로 내성이 발현되지 않아 널리 사용된다. 국내 항생제 시장의 48.6\%를 차지하고 있는 Cephalosporin 항생물질은 약효가 다른 항생물질에 비해 뛰어나다는 연구 결과가 발표된 이후(이, 2012), 가장 널리 사용되는 항생제 중 하나 이다(김, 2002).

각종 식품 알레르기, 물리적 알레르기, 호흡기 알레르기, 혈당과 인슐린, 당뇨병의 검사, 당뇨병과 질환 등의 대사성 질환에 대해서
는 많은 연구가 있었으나 알레르기와 당뇨병 발생의 관련성과 위험 성에 관한 연구가 미흡한 실정이므로 이 연구에서는 골절과 절단, 심한 외상 환자를 대상으로 알레르기와 혈당과의 관련성과 골절과 상처치료에 널리 사용되고 있는 Cephalosporin 주사 전후의 변화 를 연구하기로 하였다.

\section{재료 및 방법}

\section{1. 연구대상}

2013년 1월 1일부터 4월 30일까지 서울 송파구 N 병원 응급센터 에 내원하여 골절이나 절단, 심한 외상으로 수술을 받고 8 일 이상 입 원한 환자 164 명을 대상으로 하였다. 연구대상자 중 남성이 (99명) 으로 $61.6 \%$, 여성이 (65명)으로 38.4\%였다. 나이 구분별로는 0 20세가(18명)으로 $11.1 \%, 21$ 40세가(56명)으로 $34.6 \%, 41 ~ 60$ 세가 (88명)으로 $54.3 \%$ 였다.

\section{2. 연구방법}

\section{1) 응급센터 처치}

응급센터로 내원한 환자에게 응급처치와 함께 환자의 성명, 성 별, 나이, 체중, 키, 혈액형, 알레르기 반응 유무, 과거 병력, 현재 질 환 유무를 문진하였고, 수축기 혈압, 이완기 혈압, 체온, 항생제 민 감도 테스트, 심전도, 골절과 절단 부위 X-ray 촬영을 시행하였으 며, 수액을 투여하기 전 상박부에서 생화학 검사를 위해 $5 \mathrm{cc}$ 를 채혈 하였고, 혈액학적 검사를 위해 EDTA bottle에 $2 \mathrm{cc}$ 를 채혈하였다.

\section{2) 생화학적 검사}

수술 전 생화학 검사는 주사와 수액 투여 전 식사 여부와 상관없 이 채혈하였고, 수술 1 주 후 혈액검사는 8 시간 이상 금식 후 정맥혈 을 채혈하였다. 검사대상물은 채혈 후 30 분 이내에 3,000 rpm으로 5 분 원심분리를 하였으며, glucose, aspartate aminotransferase (AST), alanine Aminotransferase (ALT), alkaline phosphatase (ALP), blood urea nitrogen (BUN), creatinine, total protein, albumin, total bilirubin, total cholesterol (TC), C-반응성 단백 의 수치를 METRO LAB PLUS 2300 자동 분석기로 측정하였다. 혈 당은 hexokinase 법으로, total cholesterol은 enzymatic colorimetric 법으로, C-반응성 단백은 turbidimetric immuno assay 법으로 측정하였다. D3 자동혈액 분석기로 $\mathrm{WBC}, \mathrm{RBC}$, PLT, Diffcount, $\mathrm{MCV}, \mathrm{MCH}, \mathrm{MCHC}, \mathrm{RDW}, \mathrm{PDW}, \mathrm{MPV}$ 등을 검 사 하였다. 


\section{3) 알레르기 환자}

환자 164 명 중 알레르기 증상을 문진 및 입원 치료 중 주사나 약 복용 중에 발생한 알레르기 증상이 있는 환자로 선별하였다. 알레 르기 반응이 있는 환자가 32 명으로 $19.5 \%$, 정상군 환자가 89 명으 로 $77.4 \%$, 무 응답자가 5 명으로 $3 \%$ 였다. 알레르기 증상이 있는 남 성이 21 명으로 $48.8 \%$, 알레르기 증상이 있는 여성 환자가 22 명으 로 $51.2 \%$ 였다. 알레르기에 정상인 남성이 89 명으로 $55.6 \%$, 정상 여성이 71 명으로 $44.4 \%$ 였다. 남성 중 알레르기 반응이 있는 환자 가 17 명으로 $16.8 \%$, 남성 환자 정상이 81 명으로 $80.2 \%$, 무 응답자 가 3 명으로 $3 \%$ 였으며, 여성 알레르기 환자가 15 명으로 $23.8 \%$, 여 성 정상이 48 명으로 $73.0 \%$, 무 응답자가 2명으로 $3.2 \%$ 였다.

\section{4) 당뇨 환자}

당뇨 환자는 혈당검사 $120 \mathrm{mg} / \mathrm{dL}$ 이상으로 식품의약품안전처 식품의약품 안전평가원 소화계 약품과(경구용 혈당 강하제에 대한 임상시험 평가 가드 라인 개정안)의 연구에서 정한 진단규정에 따 랐다. 연구대상자 164 명 중 당뇨 환자가 25 명으로 $15.2 \%$, 정상 환 자가 137 명으로 $83.5 \%$, 검사 불응자가 2 명으로 $1.2 \%$ 였다. 당뇨 환 자 중 남성이 18 명으로 $17.8 \%$, 남성 정상이 82 명으로 $81.2 \%$, 검사 불응자가 1 명으로 $1 \%$ 였으며, 여성 당뇨 환자는 7 명으로 $11.1 \%$, 여 성 정상이 55 명으로 $87.3 \%$, 검사 불응자 1 명 $1.6 \%$ 였다.

\section{5) 통계 분석}

자료의 통계분석은 Windows SPSS Program (ver. 20, Chicago, IL, USA)을 이용하였다. 통계결과는 평균, 표준편차 또는 $95 \%$ 신뢰 구간으로 표시하였다. paired t test, chi square test, 비모수검정 K 대응표본, 기술통계, 상관관계는 Pearson 상관분석을 사용하였다.

\section{결 과}

\section{1. 연구대상자의 일반적 특성 및 생화학적 검사}

연구대상자 164 명의 성별에 따른 나이, 키, 체중의 평균이다. 연 구대상자 중 남성은 99명, 여성은 65 명으로 평균연령은 남성이
$35.8 \pm 13$ 세이었고, 여성이 $45.54 \pm 14$ 세로 여성의 나이가 많았다. 평균 키는 남성이 $171.5 \pm 7.3 \mathrm{~cm}$, 여성이 $156.6 \pm 13.3 \mathrm{~cm}$ 이었다. 체중은 남성 평균이 $71.3 \pm 13.9 \mathrm{~kg}$, 여성이 $56.6 \pm 12.9 \mathrm{~kg}$ 이었다. 수술 전 glucose, BUN, creatinine, total protein, albumin, total bilirubin AST, ALT, alkaline phosphatase, total cholesterol의 평 균이다. 수술 전 glucose는 남성과 여성 각각 $107.9 \pm 43.6 \mathrm{mg} / \mathrm{dL}$, $97.5 \pm 26.1 \mathrm{mg} / \mathrm{dL}$ 이었으며, 수술 전 BUN 남녀의 평균은 남성이 $13.7 \pm 4.1 \mathrm{mg} / \mathrm{dL}$, 여성이 $14.6 \pm 11.9 \mathrm{mg} / \mathrm{dL}$ 이었다. Creatinine 남녀의 평균은 남성이 $1.0 \pm 0.7 \mathrm{mg} / \mathrm{dL}$, 여성이 $0.9 \pm 0.2 \mathrm{mg} / \mathrm{dL}$ 이 었다. Total protein의 평균은 남성이 $8.0 \pm 0.7 \mathrm{mg} / \mathrm{dL}$, 여성이 $7.6 \pm 1.1 \mathrm{mg} / \mathrm{dL}$ 이었다. Albumin의 평균은 남성이 $4.4 \pm 0.4$ $\mathrm{mg} / \mathrm{dL} 4.2 \pm 0.6 \mathrm{mg} / \mathrm{dL}$ 이었고, total bilirubine 평균은 남성이 $0.9 \pm 0.6 \mathrm{mg} / \mathrm{dL}$, 여성이 $1.0 \pm 2.3 \mathrm{mg} / \mathrm{dL}$ 이었다. AST 평균은 남성 이 $35.3 \pm 49.5 \mathrm{mg} / \mathrm{dL}$, 여성이 $22.1 \pm 10.4 \mathrm{mg} / \mathrm{dL}$ 이었다. ALT의 평 균은 남성이 $32.8 \pm 45.2 \mathrm{mg} / \mathrm{dL}$, 여성이 $16.8 \pm 11.5 \mathrm{mg} / \mathrm{dL}$ 이었다. Alkaline phosphatase의 평균은 남성이 $85.5 \pm 45.3 \mathrm{mg} / \mathrm{dL}$, 여성 이 $78.6 \pm 47.5 \mathrm{mg} / \mathrm{dL}$ 이었다. Total cholesterol은 남성이 $187.7 \pm 38.2 \mathrm{mg} / \mathrm{dL}$, 여성이 $193.5 \pm 46.7 \mathrm{mg} / \mathrm{dL}$, 키, 체중과 albumin, ALT, AST가 남성에서 높게 나타났으며, 혈당, BUN, 총 단

Table 1. The general characteristics of the study subjects and biochemical tests

\begin{tabular}{lcc}
\hline & Men $(\mathrm{n}=99)$ & Women $(\mathrm{n}=65)$ \\
\hline Height $(\mathrm{cm})$ & $171.5 \pm 7.3$ & $156.6 \pm 13.3$ \\
Weight $(\mathrm{kg})$ & $71.3 \pm 13.9$ & $55.6 \pm 12.9$ \\
Age & $35.8 \pm 13.4$ & $45.5 \pm 14.5$ \\
glucose $(\mathrm{mg} / \mathrm{dL})$ & $107.9 \pm 43.6$ & $97.5 \pm 26.1$ \\
Bun $(\mathrm{mg} / \mathrm{dL})$ & $13.7 \pm 4.1$ & $14.6 \pm 11.8$ \\
Creatinine $(\mathrm{mg} / \mathrm{dL})$ & $1.0 \pm 0.7$ & $0.9 \pm 0.2$ \\
Total protein $(\mathrm{mg} / \mathrm{dL})$ & $7.8 \pm 0.7$ & $7.6 \pm 1.1$ \\
Albumin $(\mathrm{mg} / \mathrm{dL})$ & $4.4 \pm 0.4$ & $4.2 \pm 0.6$ \\
Total bilirubine $(\mathrm{mg} / \mathrm{dL})$ & $0.9 \pm 0.6$ & $1.0 \pm 2.3$ \\
AST $(\mathrm{mg} / \mathrm{dL})$ & $35.3 \pm 49.5$ & $22.1 \pm 10.4$ \\
ALT $(\mathrm{mg} / \mathrm{dL})$ & $32.8 \pm 45.2$ & $16.8 \pm 11.5$ \\
Alkaline phosphatase $(\mathrm{mg} / \mathrm{dL})$ & $85.5 \pm 45.3$ & $78.6 \pm 47.5$ \\
Total cholesterol $(\mathrm{mg} / \mathrm{dL})$ & $187.7 \pm 38.2$ & $193.5 \pm 46.7$ \\
\hline
\end{tabular}

(mean士SD).

Table 2. Effect of diabetes allergies

\begin{tabular}{llrrr}
\hline & & & & \multicolumn{2}{c}{$95 \%$ confidence interval } \\
\cline { 3 - 5 } & & OR odds ratio & Lower & Upper \\
\hline \multirow{2}{*}{ Total } & Odds ratio for allergies presence or absence & 3.273 & 3.273 & 8.496 \\
& Forcohort diabetes presence or absence=diabetic & 2.613 & 1.247 & 5.474 \\
& For cohort diabetes presence or absence=normal & 0.798 & 0.632 & 1.008 \\
$0 \sim 20$ y & Odds ratio for allergies presence or absence & 1.071 & 0.936 & 1.227 \\
$21 \sim 40$ y & Odds ratio for allergies presence or absence & 8.063 & 1.314 & 49.462 \\
$41 \sim 60$ y & Odds ratio for allergies presence or absence & 2.571 & 0.783 & 8.440 \\
\hline
\end{tabular}


백, total bilirubin, ALP, total cholesterol은 남녀의 차이가 없었다 (Table 1).

\section{2. 알레르기가 당뇨 환자에 미치는 영향}

알레르기 유무에 따른 당뇨 환자의 상대 위험도가 2.613임을 알 수 있었다. 이에 대한 $95 \%$ 신뢰구간은 $(1.247,5.474)$ 로 추정되었 다. 신뢰구간이 1 을 포함하므로 알레르기가 있는 환자의 당뇨병 위 험을 유의하게 증가시킨다고 할 수 있다. 0 19세는 알레르기 유무 에 따른 당뇨 환자의 상대 위험도가 $1.071,20$ 39세의 상대 위험 도는 8.063, 40 60세의 상대위험도는 2.571 임을 알 수 있다. 나 이별로는 20 39세의 알레르기가 당뇨병에 미치는 위험도가 가장 높았고, 그다음이 40 60세, 0 20세 순으로 위험도가 높았다 (Table 2).

\section{Cephalosporin 주사와 수술 1주 후 혈당과의 상관분석}

연구대상자들을 Cephalosporin 주사 후 혈당과의 상관분석을 비교하였다. Cephalosporin과 수술 후 혈당과의 상관계수는 Cephalosporin $\mathrm{r}=1 * *, *,(p<0.007)$ 로 유의한 상관관계를 나타 내었고, 수술 후 혈당의 $\mathrm{r}=-0.660,(p<0.000)$ 로 통계적으로 유의 한 상관관계를 나타냈다(Table 3).

\section{4. 알레르기 유무와 혈당의 차이}

알레르기와 당뇨병에 따른 수술 전후 남녀의 평균을 보면 남성 의 평균 키는 $171.07 \pm 0.6 \mathrm{~cm}$ 였고, 여성의 평균 키는 $154.72 \pm 1.7$ $\mathrm{cm}$ 였다. 남녀 평균 체중은 남성이 $71.34 \pm 1.1 \mathrm{~kg}$, 여성이 $55.7 \pm 0.9 \mathrm{~kg}$ 이었다. 수술 전 검사에서 알레르기 반응이 있는 남성 의 평균 혈당은 $124.9 \pm 15.9 \mathrm{mg} / \mathrm{dL}$, 여성의 평균 혈당은

Table 3. Relationship with the blood sugar and Cephalosporins injection 1 week after operation

\begin{tabular}{|c|c|c|}
\hline & Cephalosporins & 1 week after operation \\
\hline Pearson correlation & $1^{* \star *}$, & $-.660^{\star \star}$ \\
\hline Sig. (2-tailed) & $<0.007$ & $<0.000$ \\
\hline
\end{tabular}

$136.4 \pm 22.6 \mathrm{mg} / \mathrm{dL}$ 로 여성이 높았다. 알레르기 반응이 없는 남성 의 혈당 평균은 $112.2 \pm 4.7 \mathrm{mg} / \mathrm{dL}$, 여성의 평균은 $115.60 \pm 6.2$ $\mathrm{mg} / \mathrm{dL}$ 이었다. 수술 1 주 후 검사에서는 알레르기 반응 있는 남성의 평균 혈당이 $178.4 \pm 22.5 \mathrm{mg} / \mathrm{dL}$, 여성이 $178.6 \pm 20.1 \mathrm{mg} / \mathrm{dL}$ 로 남녀 모두 높았다. 알레르기가 없는 남성 환자의 평균 혈당이 $85.8 \pm 10.1 \mathrm{mg} / \mathrm{dL}$, 여성이 $80.2 \pm 10 \mathrm{mg} / \mathrm{dL}$ 이었다. 남녀 평균 나 이는 남성의 평균 $46.12 \pm 15.8$ 세, 여성은 $58.12 \pm 14.5$ 세로 여성 의 나이가 많았다(Table 4).

\section{5. 알레르기와 질환과의 상관관계}

환자의 과거와 현재의 질환 유무에 따라 분류하였고, 알레르기 와의 상관관계를 분석하여 비교하였다. 질환 유무와 알레르기 유무 와의 상관계수는 각각 $\mathrm{r}=0.176^{*},(p<0.027)$ 로 통계적으로 유의한 상관관계를 나타냈다(Table 5).

\section{Cephalosporin 주사}

연구대상자 164 명 중 항생제 Cephalosporin을 맞은 환자는

Table 5. Correlation of allergy and disease

\begin{tabular}{lccc}
\hline & $\begin{array}{c}\text { Allergies presence } \\
\text { or absence }\end{array}$ & $\begin{array}{c}\text { Presence of } \\
\text { disease }\end{array}$ \\
\hline Pearson correlation & $p$ & $<0.027$ & $<0.027$ \\
Sig. (2-tailed) & $r$ & $0.176^{*}$ & $0.176^{*}$ \\
\hline
\end{tabular}

${ }^{*}$ Correlation is significant at the 0.05 level (2-tailed).

Table 6. Cephalosporins injections

\begin{tabular}{lcrrrr}
\hline & & Frequenc & Percent & $\begin{array}{c}\text { Valid } \\
\text { percent }\end{array}$ & $\begin{array}{c}\text { Cumulative } \\
\text { ercent }\end{array}$ \\
\hline Valid & $0.3 \mathrm{cc}$ & 1 & 0.6 & 0.8 & 0.8 \\
& $0.4 \mathrm{cc}$ & 1 & 0.6 & 0.8 & 1.6 \\
& $0.5 \mathrm{cc}$ & 1 & 0.6 & 0.8 & 2.4 \\
& 1 vial & 122 & 74.4 & 97.6 & 100.0 \\
& Total & 125 & 76.2 & 100.0 & \\
Missing & System & 39 & 23.8 & & \\
Total & & 164 & 100 & & \\
\hline
\end{tabular}

Table 4. The difference of the blood sugar after and before operation with allergic presence

\begin{tabular}{lcc}
\hline & Men $(\mathrm{n}=109)$ & Women $(\mathrm{n}=91)$ \\
\hline Height $(\mathrm{cm})$ & $171.1 \pm 0.6$ & $154.7 \pm 1.7$ \\
Weight $(\mathrm{kg})$ & $71.3 \pm 1.1$ & $55.7 \pm 0.9$ \\
Before operation allergies presence blood sugar $(\mathrm{mg} / \mathrm{dL})$ & $124.9 \pm 15.9$ & $136.4 \pm 22.6$ \\
Before operation allergies absence blood sugar $(\mathrm{mg} / \mathrm{dL})$ & $112.2 \pm 4.7$ & $115.6 \pm 6.2$ \\
After operation allergies presence blood sugar $(\mathrm{mg} / \mathrm{dL})$ & $178.4 \pm 22.5$ & $178.6 \pm 20.1$ \\
After operation allergies absence blood sugar $(\mathrm{mg} / \mathrm{dL})$ & $85.8 \pm 10.1$ & $80.2 \pm 10.1$ \\
Age (year) & $46.1 \pm 15.8$ & $58.1 \pm 14.5$ \\
\hline
\end{tabular}

(mean \pm SD). 
$0.3 \mathrm{cc} 1$ 명, $0.4 \mathrm{cc} 1$ 명, $0.5 \mathrm{cc}$ 주사 1 명, 1 vial 주사가 122 명, 기타 주사제 맞은 환자가 39명 이었다(Table 6).

\section{Cephalosporin 주사 전후 생화학검사 비교}

Cephalosporin 주사 전의 혈당 및 간 기능, 신장 기능 검사와 주 사 후 변화 가 있는지 알아보았다. 주사 전후 혈당의 근사검정 결과 를 보면 검정 통계량은 $\mathrm{Z}=-2.587,(p<0.010)$ 로 통계적으로 유의 하였다. 따라서 주사 전후의 혈당 변화가 있었고, bun의 검정 통계 량은 $\mathrm{Z}=-2.235,(p<0.025)$ 로 통계적으로 유의하였다. 총 단백의 검정 통계량은 $\mathrm{Z}=-6.144,(p<0.000)$ 로 통계적으로 유의하였다. albumin의 검정 통계량은 $\mathrm{z}=-5.185,(p<0.000)$ 로 통계적으로 유 의 하였다. AST 검정 통계량은 $\mathrm{Z}=-3.184,(p<0.001)$ 로 통계적으 로 유의하였다. Total bilirubin의 검정 통계량은 $\mathrm{z}=-4.820,(p$ $<0.000)$ 로 통계적으로 유의하였다. ALP의 검정 통계량은 $\mathrm{z}=-2.498,(p<0.012)$ 로 통계적으로 유의 하였다(Table 7$)$.

\section{8. 수술 전 알레르기 반응 유무와 생화학 검사 비교}

알레르기 반응 유무에 따른 생화학 검사를 비교해 보았다. 수술 전 혈당이 알레르기 반응자가 $109.79 \mathrm{mg} / \mathrm{dL}$, 알레르기 반응 없는 환자가 $100.79 \mathrm{mg} / \mathrm{dL}$, bun이 알레르기 반응이 있는 환자가 13.2 $\mathrm{mg} / \mathrm{dL}$, 알레르기 반응 없는 환자 bun $14.1 \mathrm{mg} / \mathrm{dL}$, total protein 의 알레르기 반응이 있는 환자가 $7.8 \mathrm{mg} / \mathrm{dL}$, 반응 없는 환자가 7.7 $\mathrm{mg} / \mathrm{dL}$, albumin 알레르기 반응이 있는 환자가 $4.4 \mathrm{mg} / \mathrm{dL}$, 반응 없는 환자가 $4.3 \mathrm{mg} / \mathrm{dL}, \mathrm{AST}$ 알레르기 반응이 있는 환자가 39.3 $\mathrm{mg} / \mathrm{dL}$, 반응 없는 환자가 $28.0 \mathrm{mg} / \mathrm{dL}$, total bilirubin 알레르기 반 응 환자가 $0.8 \mathrm{mg} / \mathrm{dL}$, 알레르기 반응이 없는 환자가 $0.9 \mathrm{mg} / \mathrm{dL}$, ALP $80.5 \mathrm{mg} / \mathrm{dL}$, 알레르기 반응 없는 ALP 환자가 $82.2 \mathrm{mg} / \mathrm{dL}$ 로

Table 7. Comparison of the Effects of before and after Cephalosporins injections

\begin{tabular}{lcc}
\hline & & $\begin{array}{c}\text { Cephalosporins } \\
\text { before \& after }\end{array}$ \\
\hline before \& after glucose $(\mathrm{mg} / \mathrm{dL})$ & z & -2.587 \\
before \& after bun (mg/dL) & $p$ & $<0.010$ \\
before \& after total protein (mg/dL) & z & -2.235 \\
before \& after albumin (mg/dL) & $p$ & $<0.025$ \\
before \& after AST (mg/dL) & z & -6.144 \\
before \& after total bilirubin (mg/dL) & z & -5.000 \\
& $p$ & 0.000 \\
before \& after ALP (mg/dL) & z & -3.184 \\
& z & -2.498 \\
& $p$ & 0.012 \\
\hline
\end{tabular}

BUN, total bilirubin, ALP를 제외한 생화학 검사에서 알레르기 있 는 환자의 수치가 높았다(Table 8).

\section{고 찰}

본 연구에서는 외상환자에서 알레르기와 혈당과의 상관관계와 국내 항생제 시장의 $48.6 \%$ 를 차지하고, 화농성 연쇄구균, 연조직 감염증, 골 및 관절 감염증 예방 및 잠재 감염 치료 약효가 다른 항생 물질에 비해 뛰어나다는 연구 결과가 발표된 이후(이, 2012), 가장 널리 사용되는 항생제 중 하나인 이 반합성 Cephalosporin 생물질 광범위 항생제 주사 후 혈당 하강의 정도를 비교 검토하였다.

직업적 요인으로 미용에 사용되는 암모늄 이온 화합물에 대한 $\operatorname{IgE}$ 감작이 증가한다. 미용에 사용되는 암모늄 화합물의 반복적인 노출로 NMBAs (신경 근육차단제) 민감성에 대한 위험 요소이다 (Dong 등, 2013). 아미노필린 단일 투여 흡입 치료는 일시적이긴 하지만, 상대적으로 강력한 기관지 효과가 있다. 반복 흡입 치료는 기도 염증 억제 과민성 알레르기 항원에 의해 유도한다. 따라서 흡 입 아미노필린은 천식 치료에 유용할 수 있다(Muraki 등, 2013). 옥 시토신은 전송하는 동안 심한 알레르기 반응의 드문 원인이기도 하 다(Liccardi 등, 2013). 폴리 염화 비닐(PVC)는 직업성 천식이 가끔 보고 되었다(Song 등, 2013) 전문 청소업체 종사자들이 청소 분무 기, 표백제, 암모니아, 소독제, 혼합 제품, 특정 작업 작업이 천식 원 인으로 확인 되었다(Siracusa 등, 2013).

당뇨병은 혈관 및 신경 병증의 발달이 늦은 것이 특징인 만성질 환이기도 하다(Watanabe 등, 2013). 당뇨병은 식품의약품안전처 식품의약품 안전평가원 소화계 약품과(경구용 혈당 강하제에 대한 임상시험 평가 가드 라인 개정안)의 연구에서 당뇨병으로 진단규정

Table 8. Comparison biochemical tests after and before Cephalosporins injections before surgery

\begin{tabular}{lcr}
\hline & $\begin{array}{c}\text { Allergies presence } \\
\text { or absence }\end{array}$ & Mean \\
\hline Sugar $(\mathrm{mg} / \mathrm{dL})$ & yes & 109.8 \\
& No & 100.8 \\
Bun $(\mathrm{mg} / \mathrm{dL})$ & yes & 13.2 \\
& No & 14.1 \\
Total protein & yes & 7.8 \\
& No & 7.7 \\
Albumin $(\mathrm{mg} / \mathrm{dL})$ & yes & 4.4 \\
& No & 4.3 \\
SGOT (mg/dL) & yes & 39.3 \\
& No & 28.0 \\
Total bilirubin $(\mathrm{mg} / \mathrm{dL})$ & yes & 0.8 \\
& No & 0.9 \\
ALP $(\mathrm{mg} / \mathrm{dL})$ & yes & 80.5 \\
& No & 82.2 \\
\hline
\end{tabular}


으로 공복 혈장 혈당 $=126 \mathrm{mg} / \mathrm{dL}$, 공복혈당장애는 공복 혈장 혈당 $100 \sim 125 \mathrm{mg} / \mathrm{dL}$ 이다. 김 등(김, 2008) 대한 당뇨병 학회의 당뇨병 진단 기준을 살펴보면, 당뇨병은 공복시 채취한 혈액의 혈당치가 $126 \mathrm{mg} / \mathrm{dL}$ 이상이고, 포도당을 경구투여한 후 2시간 후에 혈당치 가 $200 \mathrm{mg} / \mathrm{dL}$ 이상인 경우를 뜻한다. 본 연구에서도 $120 \mathrm{mg} / \mathrm{dL}$ 이상을 당뇨병 기준으로 하였다. Cephalosporin은 가장 널리 사용 되는 항생제 중 하나이다(김, 2002). 본 연구에서도 연구대상자 164 명 중 Cephalosporin 주사한 환자는 $0.3 \mathrm{cc}$ 주사 1 명, $0.4 \mathrm{cc}$ 주사 1 명, $0.5 \mathrm{cc}$ 주사 1 명, $1 \mathrm{vial}$ 주사 122 명, 기타주사제 맞은 환 자가 39 명으로 전체 환자의 76.2\%를 Cephalosporin을 주사했다 (Table 6).

박 등(박, 2007) 제 2 형 당뇨병 환자에서 대사증후군 유의 연구에 서 당뇨병의 관련성을 분석한 결과 고중성지방혈증, $\mathrm{HDL}$-콜레스 테롤, 고혈압 순으로 유의한 상관관계가 있다고 보고되었다. 본 연 구에서 알레르기가 당뇨 환자에 미치는 영향을 분석한 결과 알레르 기에 따른 당뇨 환자의 상대 위험도가 2.613 임을 알 수 있었다. 이 에 대한 $95 \%$ 신뢰구간은 $(1.247,5.474)$ 로 추정되었다. 신뢰구간 이 1 을 포함하므로 알레르기가 있는 환자의 당뇨병 위험을 유의하 게 증가시킨다고 할 수 있다. 환자의 과거와 현재의 질환 유무에 따 라 분류하고, 알레르기와의 상관관계를 분석하여 비교하였다.

생화학 검사를 알레르기 유무에 따라 비교해본 결과를 보면, glucose 알레르기 반응이 있는 환자가 $109.8 \mathrm{mg} / \mathrm{dL}$, 알레르기 반 응 없는 환자가 $100.8 \mathrm{mg} / \mathrm{dL}, \mathrm{BUN}$ 이 알레르기 반응이 있는 환자 가 $13.3 \mathrm{mg} / \mathrm{dL}$, 알레르기 반응 없는 환자가 $14.1 \mathrm{mg} / \mathrm{dL}$, total protein 알레르기 반응이 있는 환자가 $7.8 \mathrm{mg} / \mathrm{dL}$, 반응 없는 환자 가 $7.7 \mathrm{mg} / \mathrm{dL}$, albumin 알레르기 반응이 있는 환자가 $4.4 \mathrm{mg} / \mathrm{dL}$, 반응 없는 환자가 $4.3 \mathrm{mg} / \mathrm{dL}, \mathrm{AST}$ 알레르기 반응이 있는 환자가 $39.3 \mathrm{mg} / \mathrm{dL}$, 반응 없는 환자가 $28.0 \mathrm{mg} / \mathrm{dL}$, total bilirubin 알레르 기 반응이 있는 환자가 $0.8 \mathrm{mg} / \mathrm{dL}$, 알레르기 반응이 없는 환자가 $0.9 \mathrm{mg} / \mathrm{dL}, \mathrm{ALP}$ 알레르기 반응이 있는 환자가 $80.5 \mathrm{mg} / \mathrm{dL}$, 알레르 기 반응 없는 환자가 $82.2 \mathrm{mg} / \mathrm{dL}$ 이었다. Glucose, total protein, albumin, AST는 알레르기 반응이 있는 환자들이 높았고, bun과 total bililubin, ALP에서만 알레르기 반응이 없는 환자의 수치가 높 았다.

당뇨는 대사 증후군의 하나이다. 인슐린 저항성은 인슐린 분비 가 증가하더라도 포도당 이용은 감소한 상태다. 기존 당뇨병 제재 는 혈당 조절에 탁월한 효과를 보이지만 당 대사를 근본적으로 조 절하거나 특정 단백질에만작용하는 것이 아니어서 저혈당이나 신 부전 등 부작용을 초래할 수 있다는 한계가 있다(최 등, 2013). 인체 내에서 혈당은 간과 췌장에 의해 조절된다. 췌장은 혈당 농도에 따 라 인슐린을 분비하여 체내 당 흡수와 분해를 촉진한다. 간은 음식
을 통해 혈액으로 들어오는 당을 급속히 흡수, 분해 저장하여 급격 한 혈당상승을 막는다. 특히 간은 공복 시 저장했던 당을 혈액 중으 로 보내는 유일한 기관으로 혈당 항상성 유지의 중추적인 기관이 며, 당을 에너지원으로 하는 뇌의 공복시 기능 유지를 위해 중요하 다(김 등, 2013).

연구대상자들을 Cephalosporin 주사 후 혈당과 상관분석을 하 여 비교하였다. Cephalosporin과 수술 후 혈당과의 상관계수는 Cephalosporin이 $\mathrm{r}=1 * *, *,(p<0.007)$, 수술 후 혈당의 $\mathrm{r}=-0.660$ 으로 통계적으로 유의한 상관관계 $(p<0.000)$ 를 나타냈다(Table 4). 알레르기와 당뇨병에 따른 수술 전 검사에서 알레르기 반응이 있는 남성의 평균 혈당은 $124.9 \pm 15.9 \mathrm{mg} / \mathrm{dL}$ 이었고, 여성의 평균 혈당은 $136.4 \pm 22.6 \mathrm{mg} / \mathrm{dL}$ 로 여성이 높았다. 알레르기 반응이 없 는 남성의 혈당 평균은 $112.2 \pm 4.7 \mathrm{mg} / \mathrm{dL}$ 이었고, 여성의 평균은 $115.6 \pm 6.2 \mathrm{mg} / \mathrm{dL}$ 이었다. 수술 후 검사에서는 알레르기 반응 있는 남성의 평균이 $178.4 \pm 22.5 \mathrm{mg} / \mathrm{dL}$ 이었고, 여성이 $178.6 \pm 20.1$ $\mathrm{mg} / \mathrm{dL}$ 로 남녀 모두 높았다. 알레르기가 없는 남성 환자의 평균 혈 당이 $85.8 \pm 10.1 \mathrm{mg} / \mathrm{dL}$, 여성이 $80.2 \pm 10.1 \mathrm{mg} / \mathrm{dL}$ 이었다. 남녀 평균 나이는 남성의 평균나이가 $46.1 \pm 15.8$ 세, 여성은 $58.1 \pm 14.5$ 세로 여성의 나이가 많았다. C-반응성 단백의 남녀 평균은 남성이 $0.28 \pm 0.2 \mathrm{mg} / \mathrm{dL}$, 여성이 $0.31 \pm 0.2 \mathrm{mg} / \mathrm{dL}$ 이었다. 김 등(김 등. 2013)에 의하면 뇌경색의 요인은 고혈압과 당뇨병이라고 보고 했 다. 장 등(장, 2008.)의 연구에서는 당뇨병 군에서 체질량지수, 수축 기 혈압, 공복혈당과 당화혈색소가 유의하게 높다고 보고되었다. 본인의 연구에서도 공복혈당이 유의하게 높았고, 알레르기 반응을 일으키는 환자가 수술 전 검사에서 알레르기 반응이 있는 남성의 평 균 혈당은 $124.9 \pm 15.9 \mathrm{mg} / \mathrm{dL}$ 이었고, 여성의 평균 혈당은 $136.4 \pm 22.6 \mathrm{mg} / \mathrm{dL}$ 이었다. 알레르기 반응이 없는 남성의 혈당 평 균은 $112.2 \pm 4.7 \mathrm{mg} / \mathrm{dL}$, 여성의 평균은 $115.6 \pm 6.2 \mathrm{mg} / \mathrm{dL}$ 이었 다. 수술 1 주 후 검사에서는 알레르기 반응 있는 남성의 평균이 $178.4 \pm 22.5 \mathrm{mg} / \mathrm{dL}$, 여성이 $178.6 \pm 20.1 \mathrm{mg} / \mathrm{dL}$ 로 남녀 모두 높 았다. 알레르기가 없는 남성 환자의 평균 혈당이 $85.8 \pm 10.1$ $\mathrm{mg} / \mathrm{dL}$, 여성이 $80.2 \pm 10.1 \mathrm{mg} / \mathrm{dL}$ 로 수술 전과 후 모두 정상 환자 보다 알레르기 환자의 혈당이 높았다. 알레르기 유무에 따른 당뇨 환자의 상대 위험도가 3.273 임을 알 수 있다. 이에 대한 $95 \%$ 신뢰구 간은 $(1.247,5.474)$ 로 추정되었다. 신뢰구간이 1 을 포함하므로 알 레르기가 있는 환자의 당뇨병 위험을 유의하게 증가시킨다고 할 수 있다(Table 2).

0 19세의 알레르기 유무에 따른 당뇨 환자의 상대 위험도가 $1.071,20$ 39세의 상대 위험도는 8.163, 40 \%0세의 상대위험 도는 2.571임을 알 수 있다. 연령별로는 20 39세의 알레르기가 당뇨병에 미치는 위험도가 가장 높았고, 그다음이 40 60세, 0 
20세 순으로 위험도가 높았다(Table 2).

이 연구의 제한점으로는 첫 번째 연구대상 인원이 164 명으로 적 었다는 점이다. 두 번째는 정형외과 미세 접합 전문병원에서 수술 받은 사람으로 전체 인구 집단의 대표할 수 없었다는 점, 세 번째는 내과가 아니어서 당뇨 검사의 기본이며, 중요한 당화혈색소의 검사 를 하지 못했다는 점, 다섯 번째로는 알레르기 환자의 알레르기 반 응 유무는 피부반응 검사나 혈청 면역 글로블린(IgE) 검사를 시행하 지 못하였고, 환자에게 문진과 치료 중 약물 알레르기 반응에 국한 된 점의 보완이 필요하다고 본다.

그러나 외상환자에서 알레르기와 혈당과 상관관계가 있었고, Cephalosporin 주사 후 혈당과도 상관관계가 확인 되었으며, 알레 르기와 환자의 과거력과도 상관관계가 있으므로, 당뇨 환자의 알레 르기 질환으로 인한 합병증을 막는 데 중요한 지표가 될 것으로 본 다.

\section{결 론}

본 연구에서는 외과 환자에서 알레르기와 혈당과 연관성과 항생 제 Cephalosporin 주사 전후 혈당의 변화를 알아보고자 164 명을 대상으로 성별에 따라 나이, 키, 체중, glucose, bun, creatinine, total protein, albumin, total bilirubin, AST, ALT, alkaline phosphatase (ALP), total cholesterol, C-반응성 단백을 비교분 석 하였고, Cephalosporin 주사 후 혈당과의 상관분석을, 환자의 과거와 현재의 질환 유무에 따라 분류하고, 알레르기와의 상관관계 를 분석, Cephalosporin 주사 전 후의 혈당 및 간 기능 및 신장 기능 검사의 변화 및 혈당의 치료 효과에 차이가 있는지 비모수 검정으 로 분석하였다. 연구대상자의 일반적 특성에서는 키와 체중에서 남 성이 여성보다 높았고, 나이에서 여성이 남성보다 높았다. 생화학 적 검사 결과에서는 glucose, creatinine, total protein, albumin, AST, ALT, alkaline phosphatase에서 남성이 높았고, bun, total bilirubin, total cholesterol, C-반응성 단백에서는 여성이 높았 다. 알레르기가 당뇨 환자에 미치는 영향에서는 알레르기 유무에 따른 당뇨 환자의 상대 위험도가 3.273 임을 알 수 있었고, 이에 대 한 $95 \%$ 신뢰구간은 $(1.247,5.474)$ 로 추정되었다. 신뢰구간이 1을 포함하므로 알레르기가 있는 환자의 당뇨병 위험을 유의하게 증가 시킨다고 할 수 있다.

연구대상자들을 Cephalosporin 주사 후 혈당과의 상관분석을 하여 비교하였다. Cephalosporin 과 수술 후 혈당과의 상관계수는 Cephalosporin 이 r=1**,*, $(p<0.007)$, 수술 후 혈당의 $\mathrm{r}=-0.660,(p<0.000)$ 로 통계적으로 유의한 상관관계를 나타냈다.

알레르기 유무에 따른 수술 전후 혈당의 차이는 알레르기와 당뇨 병에 따른 수술 전후 남녀의 평균을 보면 남성의 평균 키는
$171.1 \pm 0.6$ 이고, 여성의 평균 키는 $154.7 \pm 1.7$ 이었다. 남녀 평균 체중은 남성이 $71.3 \pm 1.1$ 이었고, 여성이 $55.7 \pm 0.9$ 이었다. 수술 전 검사에서 알레르기 반응이 있는 남성의 평균 혈당이 $124.9 \pm$ 15.9 , 여성의 평균 혈당은 $136.4 \pm 22.6$ 이었다. 알레르기 반응이 없 는 남성의 혈당 평균은 $112.2 \pm 4.7$, 여성의 평균은 $115.6 \pm 6.2$ 이 었다. 수술 1 주 후 검사에서는 알레르기 반응 있는 남성의 평균이 $178.4 \pm 22.5$, 여성이 $178.6 \pm 20.1$ 로 남녀 모두 높았다. 알레르기 가 없는 남성 환자의 평균 혈당이 $85.8 \pm 10.1$, 여성이 $80.2 \pm 10.1$ 이었다. 남녀 평균나이는 남성의 평균 나이가 $46.1 \pm 15.8$ 세, 여성 은 $58.1 \pm 14.5$ 세로 여성이 많았다. C-반응성 단백의 남녀 평균은 남성이 $0.28 \pm 0.19$, 여성이 $0.31 \pm 0.16$ 이었다. 남녀의 수술 전 혈 당이 알레르기를 일으키는 환자가 알레르기를 일으키지 않는 환자 보다 남녀 모두 높았고, 수술 1주 후 검사에서도 알레르기를 일으키 는 환자가 일으키지 않는 환자보다 유의하게 높음을 확인했다. 0 19세는 알레르기 유무에 따른 당뇨 환자의 상대 위험도가 1.071, 20 39세의 상대 위험도는 8.063, 40 60세의 상대위험도는 2.571임을 알 수 있었다. 나이별로는 20 39세의 알레르기가 당뇨 병에 미치는 위험도가 가장 높았고, 그다음이 40 60세, 0 20세 순으로 위험도가 높았다(Table 3).

환자의 과거와 현재의 질환 유무에 따라 알레르기와의 상관관계 를 분석하여 비교하였다. 질환 유무와 알레르기 유무와의 상관계수 는 각각 $\mathrm{r}=0.176,(p<0.027)$ 로 통계적으로 유의한 상관관계를 나 타냈다.

Cephalosporin 주사 후 주사 전의 혈당 및 간 기능, 신장 기능 검 사와 주사 후의 혈당의 변화가 있는지 알아보았다. 주사 전후 혈당 의 근사검정 결과를 보면 검정 통계량은 $\mathrm{Z}=-2.587,(p<0.010)$ 로 통계적으로 유의하였다. 따라서 Cephalosporin 주사 후 혈당의 변 화 있었다. bun의 검정 통계량은 $\mathrm{z}=-2.235,(p<0.025)$ 로 주사 후 통계적으로 유의하였고. 총 단백의 검정 통계량은 $\mathrm{z}=-6.144,(p$ $<0.000$ )로 통계적으로 유의하였다. Albumin의 검정 통계량은 $\mathrm{Z}=-5.185,(p<0.000)$ 으로 통계적으로 유의하였으며, ALT 검정 통계량은 $\mathrm{Z}=-3.184,(p<0.001)$ 로 통계적으로 유의하였다. Total bilirubin의 검정 통계량도 $\mathrm{z}=-4.820,(p<0.000)$ 로 통계적으로 유의하였다. ALP의 검정 통계량은 $\mathrm{Z}=-2.498,(p<0.012)$ 로 ALP 도 통계적으로 유의하였다.

외상환자에서 알레르기가 당뇨병 발생률을 유의하게 높이는 것 을 확인했고, 광범위 항생제 Cephalosporin이 혈당수치를 유의하 게 낮추는 역할을 하는 것을 확인했다. 그러므로 외상환자 치료에 서 당뇨병을 높이는 요인인 알레르기를 철저히 예방하는 하는 지표 가 될 수 있다고 본다. 


\section{참고문헌}

Arulraj R, Venkatesh C, Chhavi N, Soundararajan P. Hypersensitivity due to ceftriaxone mimicking measles in a child. Department of Pediatrics, Mahatma Gandhi Medical College and Research Institute, Pillaiyarkuppam, Puducherry 607 402, India. Indian J Pharmacol. 2013, 45:528-9. doi: 10.4103/0253-7613.117756.

Bamanikar A, Dhobale S, Lokwani S. Pregabalin hypersensitivity in a patient treated for postherpetic neuralgia. Department of Medicine, Padmashree Dr. D.Y. Patil Medical College Hospital and Research Center, Dr. D.Y. Patil Vidyapeeth, Pimpri, Pune, Maharashtra, India. Indian J Pharmacol. 2013, 45:522-3. doi: 0.4103/0253-7613.117748.

Becker TM, Durrani SR, Bochkov YA, Devries MK, Rajamanickam V, et al. Effect of exogenous interferons on rhinovirus replication and airway inflammatory responses.Department of Pediatrics, University of Wisconsin School of Medicine and Public Health, Madison, Wisconsin. Ann Allergy Asthma Immunol. 2013, 111:397-401. doi: 10.1016/j.anai.2013.07.029. Epub 2013 Aug 28.

Cornere MM. North Shore Hospital, Westlake, Auckland, New zealand. Chronic cough: a respiratory viewpoint. Curr Opin Otolaryngol Head Neck Surg. 2013 Oct 23.

de Boer JD, Yang J, van den Boogaard FE, Hoogendijk AJ, de Beer R, et al. Mast Cell-Deficient Kit Mice Develop House Dust Mite-Induced Lung Inflammation despite Impaired Eosinophil Recruitment. JInnate Immun. 2013 Oct 18.

Dong S, Acouetey DS, Guéant-Rodriguez RM, Zmirou. Navier D, Rémen T, et al. Prevalence of IgE against neuromuscular blocking agents in hairdressers and bakers. Guéant JL. Clin Exp Allergy. 2013, 43:1256-1262. doi: 10.1111/cea.12189.

Erkoçoglu M, Kaya A, Ozcan C, Akan A, Vezir E, et al. The Effect of Obesity on the Level of Fractional Exhaled Nitric Oxide in Children with Asthma. Department of Pediatric Allergy and Immunology, Ankara Children's Hematology Oncology Education and Research Hospital, Ankara, Turkey.nt Arch Allergy Immunol. 2013, 162:156-162. doi: 10.1159/000351454.

Holgate ST.Mechanisms of Asthma and Implications for Its Prevention and Treatment: A Personal Journey. Allergy Asthma Immunol Res. 2013, 5:343-347. Epub 2013 Jun 25.

Jang Y, Kim E. Cardiovascular effect of epinephrine in endodontic microsurgery: a review. Restor Dent Endod. 2013, 38:187-193. Epub 2013 Nov 12.

Kinoshita T, Baatjes A, Smith SG, Dua B, Watson R, et.al. Natural regulatory $\mathrm{T}$ cells in isolated early responders compared with dual responders with allergic asthma. J Allergy Clin Immunol. 2013 Oct 15. pii: S0091 6749(13)01339-0. doi: 10.1016/j.jaci.2013.08.025.

Laemmle, Ruff I, O'Hehir R, Ackland M, Tang ML. Anaphylaxis identification, management and prevention. Aust Fam Physician. 2013, 42(1-2):38-42.

Lazovic B, Milenkovic V, Delic M, Mazic S, Jeremic K, Hrgovic Z. Hypersensitivity to Etoposide in case of metastatic gestational choriocarcinoma. Case Rep Oncol. 2013, 6:490-492. doi: 10.1159/000353627.

Liccardi G, Bilò MB, Mauro C, Salzillo A, Piccolo A, et al. Oxytocin: an unexpected risk for cardiologic and broncho obstructive effects, and allergic reactions in susceptible delivering women. Multidiscip Respir Med. 2013, 8:67.

Muraki M, Wada S, Ohno T, Hanada S, Sawaguchi H. et al. Effects of inhaled aminophylline on airway constriction and inflammation in ovalbumin sensitized guinea pigs. Department of Respiratory Medicine and Allergology, Nara Hospital, Kinki University Faculty of Medicine, Ikoma, Japan and. Drug Deliv. 2013 Oct 23.

Ozkaya E. Istanbul Üniversitesi Istanbul Tip Fakültesi, Deri ve Zührevi Hastaliklar Anabilim Dali, 34093 Istanbul, Turkey. Eczematous type multiple drug allergy from isoniazid and ethambutol with positive patch test results-Cutis. 2013, 92:121-4.

Park KJ, Moon JY, Hs JS, Kim SD, Pyun BY, et al. Impacts of heavy rain and typhoon on allergic disease. Osong Public Health Res Perspect. 2013, 4:140-145. doi: 10.1016/j.phrp.2013.04.009. Epub 2013 Apr 30.

Parsons KS, Hsu AC, Wark PA. TLR3 and MDA5 signalling though not expression, is impaired in asthmatic epithelial cells in response to rhinovirus infection. Centre for Asthma and Respiratory Disease and Hunter Medical Research Institute, The University of Newcastle, Australia.Clin Exp Allergy. 2013 Oct 17. doi: 10.1111/cea.12218.

Pleasants RA, Ohar JA, Croft JB, Liu Y, Kraft M, et al. Herrick HLChronic Obstructive Pulmonary Disease and Asthma Patient Characteristics and Health Impairment. 1Campbell University College of Pharmacy and Health Sciences and Division of Pulmonary, Allergy, and Critical Care Medicine, Duke University School of Medicine, Durham, NC, USA. COPD. 2013 Oct 23.

Pouliot MC, Despres JP, Nadeau A, Moorjani S, Prud'Homme D, et, al. Visceral obesity in men. Association with glucose tolerance, plasma insulin, and lipoprotein levels. Diabetes. 1992, 41:826-834.

Shim EJ, Chun E, Kang HR, Cho SH, Min KU, Park HW. Expression of semaphorin $3 \mathrm{~A}$ and neuropilin 1 in asthma. J Korean Med Sci. 2013, 28:1435-1442. doi: 10.3346/jkms.2013.28.10.1435. Epub 2013 Sep 25. PMID: 24133346

Simms E, Kjarsgaard M, Denis S, Hargreave FE, Nair P, Larché M. Cytokine responses of peripheral blood mononuclear cells to allergen do not identify asthma or asthma phenotypesClin Exp Allergy . 2013, 43:1226-35.

Siracusa A, De Blay F, Folletti I, Moscato G, Olivieri M, et al. Asthma and exposure to cleaning products a European Academy of Allergy and Clinical Immunology task force consensus statement. Department of Occupational Medicine, University of Perugia, Perugia, Italy. Allergy. 2013 Oct 16. doi: 10.1111/all.12279.

Song GW, Ban GY, Nam YH, Park HS, Ye YM. et al. Case report of occupational asthma induced by polyvinyl chloride and nickel. Ye YM. Department of Allergy and Clinical Immunology, Ajou University School of Medicine, Suwon, Korea. J Korean Med Sci. 2013, 28:1540-1542. doi: 10.3346/jkms.2013.28.10.1540.

Toyota I, Tanida M, Shibamoto T, Wang M, Kurata Y, et al. MRI reveals edema in larynx (but not in brain) during anaphylactic hypotension in anesthetized rats. Department of Radiology, Kanazawa Medical University, Uchinada, Japan. Allergy Asthma Immunol Res. 2013, 5:389-396.

Waanders F, Visser FW, Gans RO. Current concepts in the management of diabetic nephropathy. Neth J Med. 2013, 71:448-458.

Watanabe Y, Singamsetty S, Zou B, Guo L, Stefanovski D, et al. Exogenous Glucose Administration Impairs Glucose Tolerance 
and Pancreatic Insulin Secretion during Acute Sepsis in Non-Diabetic Mice. Division of Pulmonary, Allergy, and Critial Care Medicine, University of Pittsburgh School of Medicine, Pittsburgh, Pennsylvania, United States of America. PLoS One. 2013, 8:e67716.

김명숙. Cephalosporin Acylase의 CephalosporinC (CPC) activity 증진 을 위한 연구. 영남대학교 대학원 응용화학과. 2002. 12.

김성옥, 이주향. 갑작스레 발병하는 뇌경색증 고혈압, 당뇨병 등 위험요인 관 리가 중요. 건강보험정책연구원. 2013.

김정희. 직장 당뇨 인의 삶의 질 영향 요인 연구. 이화여자대학교 대학원. 2008.

김학성, 최정민. 간에서의 혈당조절 메커니즘-한국과학기술단체총연합. 2013.

박철진. 제2형 당뇨병 환자에서 대사증후군 유병률 및 관련 요인의 특징.
2007.

박현정. Evaluation of Dipeptidly Peptidase 4 Ihibitor for Type 2 Diabetes mellitus in Korean Patients. 충북대학교 임상약학대학원.

박화선. 당뇨병 환자의 한국어판 스트레스 평가지. 가천의과대학교 의학전문 대학원. 2011.235.

이주연. Removal Characteristics of pharmaceutical Compounds (Cephalosporins) by MF and UF Membranes. 서울시립대학교대학원 환경공학부 2012. 2월.

장경순. 지역사회주민에서 당뇨병 유병률 및 심박동수 변이에 영향을 미치는 요인. 동국대학교 의학과. 2008.

정윤정. 노인 제 2 형 당뇨병 환자의 정신건강 상태 및 영향 인자 분석. 아주대 학교대학원 의학과 의학전공.

최도영, 김래수, 최흥식, 구승회. 저분자 물질(G나5182)이 포도당 생성에 관 여하는 단백질 활성을 억제하여 혈당 완화. 미래창조과학부. 2013. 